\title{
Physiological factors affecting the rapid decrease in protein assimilation efficiency by a caterpillar on newly-mature tree leaves
}

\author{
R A Y M O N V. B ARBEHEN ${ }^{1,2}$, NOLA HA U G B R G ${ }^{1}$, J OSEPH \\ K OCHMANSKI ${ }^{1}$, B R A D O N M N A C E M ${ }^{1}$ and C HELSEA M IL L R ${ }^{3}$ \\ ${ }^{1}$ Department of Molecular, Cellular and Developmental Biology, University of Michigan, Ann Arbor, Michigan, U.S.A., \\ ${ }^{2}$ Department of Ecology and Evolutionary Biology, University of Michigan, Ann Arbor, Michigan, U.S.A. and ${ }^{3}$ Department of \\ Biology, Kalamazoo College, Kalamazoo, Michigan, U.S.A.
}

\begin{abstract}
Lymantria dispar L. caterpillars have a decreased ability to assimilate protein from mature leaves of red oak (Quercus rubra) compared with young, expanding leaves. The present study determines whether the drop in protein assimilation efficiency (PAE) occurs during the rapid phase of leaf maturation. Several mechanisms that might account for decreased PAE are also examined: mature leaf tissues could resist being chewed efficiently, protein in mature leaf tissues could become difficult to extract, and other nutrients in mature leaves might become growth limiting. The entire seasonal decrease in PAE occurs rapidly (in less than 2 weeks), when the leaves finished expanding. The maturation process is characterized by increased levels of fibre and decreased levels of water but no significant changes in the levels of protein or carbohydrates. Despite increased fibre in mature leaves, they are not chewed into larger food particles than are immature leaves. Carbohydrate assimilation efficiencies remain high on mature leaves, and signs of limiting water levels in larvae of $L$. dispar on mature leaves are not observed. The most important finding in the present study is the decreased extractability of protein in food particles from mature leaves, which plays a major role in explaining the rapid decrease in PAE. It is hypothesized that structural changes in cell walls during the rapid process of leaf maturation decrease protein extractability, which, in turn, greatly decreases the nutritional quality of mature oak leaves for caterpillars. The results of the present study therefore suggest a general mechanism to help explain the widely documented decrease in the nutritional quality of the mature leaves of many tree species for herbivorous insects.
\end{abstract}

Key words. Amino acid, digestion, herbivore, Lymantria dispar, nutritional ecology.

\section{Introduction}

One of the most striking developmental changes in the foliage of temperate deciduous trees is the shift from lush, light green expanding leaves to tough, darker green mature leaves in the spring. This rapid process appears to be triggered when leaves

Correspondence: Raymond V. Barbehenn, Department of Molecular, Cellular and Developmental Biology, University of Michigan, Ann Arbor, Michigan 48109-1048, U.S.A. Tel.: +1 734-764-2770; e-mail: rvb@umich.edu reach their full size. The nutritional suitability of tree leaves for caterpillars decreases greatly as the leaves mature (Hough \& Pimentel, 1978; Schweitzer, 1979; Raupp \& Denno, 1983; Schroeder, 1986; Raupp et al., 1988; Hunter \& Lechowicz, 1992; Parry et al., 1998). For example, in as little as 1 week, the survivorship and growth rates of larvae of Lymantria dispar L. on four tree species are significantly decreased by leaf maturation (Raupp et al., 1988). In a seminal paper, Feeny (1970) also notes that 'some change or combination of changes occurs in oak leaves over a period of only $2-3$ weeks in late May which has a markedly adverse effect on the larval growth 
rates, pupal weights, and adult emergence of the winter moth.' Feeny (1970), and subsequent researchers, find that expanding tree leaves are rich in nitrogen and water, and have low levels of fibre and toughness, each of which could provide nutritional benefits (Scriber \& Slansky, 1981).

Protein (or nitrogen) is often considered to be the most limiting macronutrient for caterpillars (Mattson, 1980; Coley et al., 2006). Thus, it is logical to postulate that the acquisition of protein by caterpillars would be lower on mature foliage either because of lower foliar protein levels, decreased availability, or both. Previously, protein assimilation efficiency (PAE) was hypothesized to be decreased by increased levels of tannins or fibre. For example, increased levels of condensed tannins were believed to decrease the availability of protein in tree leaves to caterpillars (Feeny, 1970). Subsequently, it has been shown that tannins do not decrease protein assimilation by insect herbivores (Bernays, 1978; Martin et al., 1987; Karowe, 1989; Barbehenn et al., 2009a). It is also proposed that protease inhibitors might decrease PAE, although this is highly unlikely in mature leaves because higher levels of protease inhibitors occur in immature than in mature leaves (Cipollini \& Bergelson, 2000; Haruta et al., 2001). We are unaware of other chemical defences in trees that may interfere with protein assimilation to a greater extent in mature than immature leaves.

The protein:carbohydrate ratio is also considered to be a key determinant of nutritional quality (Behmer, 2009). On artificial diets, a variety of caterpillar and grasshopper species adjust their intake and/or metabolism of nutrients to obtain a specific nutrient balance. If $L$. dispar larvae that fed on mature leaves were unable to obtain sufficient levels of carbohydrates compared with those available from young leaves, it is possible that they would decrease their PAEs to optimize their protein/carbohydrate balance (Clissold et al., 2010). We are unaware of any previous work that has examined this question with caterpillars on leaves.

Leaf tissues complicate the abilities of caterpillars to acquire nutrients because of the limitations imposed by leaf tissue structure. Fibre, as a structural component of cell walls and a source of toughness, decreases PAE in locusts compared with wall-free leaf preparations (Clissold et al., 2009). However, it remains unclear whether PAE in insect herbivores is affected adversely by intermediate levels of fibre, such as the levels in mature versus immature leaves. Increased levels of fibre in mature leaves do have the obvious effect of increasing leaf toughness, which is associated with a decreased consumption rate (Choong, 1996). In addition, it is possible that PAE might be decreased in caterpillars feeding on mature leaves because the greater toughness of these leaves may result in the formation of larger food particle sizes, which would leave a larger fraction of cells intact and increase the diffusion pathway of protein to the gut fluid. The present study tests this possibility.

The suggestion that lower levels of water in mature foliage might explain reduced protein utilization is based, in large part, upon the finding that low water levels can become the growthlimiting nutrient in artificial diet (Martin \& Van't Hof, 1988). Water is a necessary nutrient for the hydration of growing insect tissues (Martin \& Van't Hof, 1988). When water limits growth, a decreased fraction of the assimilated amino acids is used for protein synthesis, and the excess amino acids are commonly excreted as waste nitrogen products (Horie \& Watanabe, 1983; Martin \& Van't Hof, 1988). However, artificial agar-based diets are an unsatisfactory model system for mature foliage because they lack the structural features of leaf tissues and are not difficult to chew. In the present study, experiments are conducted in a way that tests whether limiting levels of water could help explain decreased protein assimilation in larvae on mature leaves.

For the study of mechanisms that might explain the reduced nutritive value of mature foliage, it is important to distinguish between three sequential processes: protein digestion, protein assimilation and protein utilization. Digestion refers to the enzymatic hydrolysis of proteins extracted from leaf tissues. Assimilation is the absorption from the midgut of amino acids (and small peptides) derived from the digestion of proteins. Utilization is the increase in body mass as a result of protein synthesis using amino acids that have been assimilated into the haemocoel from the midgut. Thus, protein could be extracted from leaf tissues and assimilated efficiently but 'dumped' as waste nitrogen, such as when water becomes limiting. Alternatively, protein could potentially be extracted from leaf tissues but not be digested or assimilated (producing a low PAE). Such distinctions are important in the present study to understand the potential role of leaf tissue structure and processing on PAE. [Note that the term 'protein utilization efficiency' (Barbehenn et al., 2013a) is no longer used synonymously with PAE.]

The insect-plant system used to examine factors that might affect PAE is L.dispar L. (gypsy moth) and Quercus rubra L. (red oak). Red oak is among the most favourable of a few hundred tree species used by L. dispar (Montgomery, 1990; Liebhold et al., 1995). In southeastern Michigan, red oak leaves contain relatively low levels of oxidatively-active phenolic compounds, and no significant increases in either phenolic compounds or toxicity are found as red oak leaves mature (Barbehenn et al., 2008, 2013a). Oak protein quality (i.e. the balance of essential amino acids) remains similar in immature and mature leaves (Barbehenn et al., 2013b). However, L. dispar larvae grow at over twice the rate and have a two-fold greater protein assimilation rate (PAR) on immature versus mature leaves (Barbehenn et al., 2013a). The purpose of the present study is to examine three main factors that might decrease PAE from mature tree leaves by $L$. dispar caterpillars: leaf chewing efficiency, protein extractability and growth-limiting levels of foliar carbohydrates or water.

To document the changes in nutritional quality that occur during leaf maturation, measurements are made of total protein, carbohydrate, water and fibre levels. To examine whether mature leaves decrease the efficiency of chewing, food particle sizes are measured in the guts of larvae that have fed on young or mature leaves. To examine whether changes in mature leaf tissues decrease the extractability of protein, the amounts of protein remaining in food particles in the guts and frass of larvae that have fed on young or mature leaves are compared. To test the hypothesis that PAE decreases as a result of decreased carbohydrate assimilation from mature leaves, 
carbohydrate assimilation efficiencies of larvae on young and mature leaves are compared. To examine whether water might become limiting, an investigation of whether assimilated amino acids are metabolized and excreted as increased levels of waste nitrogen by larvae on mature (low water) leaves is performed. To examine the possibility that larvae extract and digest protein efficiently but avoid absorbing the excess amino acids from the gut, an examination is made as to whether there is an increase in free amino acids in the frass of larvae on mature leaves. Based on the results obtained, a general mechanism is proposed to help explain the reduced nutritional value of mature oak foliage.

\section{Materials and methods}

\section{Insects}

Lymantria dispar eggs were obtained from the United States Department of Agriculture (USDA, Otis Air Force Base, Massachusetts). Larvae were reared primarily at $23^{\circ} \mathrm{C}$ (LD $16: 8 \mathrm{~h}$ ) on an artificial diet (Addy, 1969) that was modified by using linseed oil instead of wheat germ oil. Larvae were hatched at three separate times to produce experimental insects. Newly-moulted fifth-instar larvae were switched to oak leaves for each experiment.

\section{Plants}

Red oak trees $(n=3)$ that had been used in previous experiments (Barbehenn et al., 2009b) were used as a source of leaves for each experiment. These trees were used in early and late May based on the appearance of their leaves; in early May they were light green and had a soft texture, whereas, in late May, they had become dark green and stiff. Leaves were removed from branches and their petioles were placed immediately in tubes of water. Within $30 \mathrm{~min}$, they were washed under water with a sponge before cutting them into $2.5-\mathrm{cm}$ diameter disks, avoiding the midrib. The use of leaf disks permitted accurate measurements of consumption by providing amounts of food that would be largely consumed (Schmidt \& Reese, 1986). Leaf disks, equally representing the three trees, were mixed to eliminate potential between-tree variation from each experiment.

\section{Foliar nutritional quality}

Protein was measured with high performance liquid chromatography (HPLC), as total amino acids (peptide-bound plus free). Frozen $\left(-80^{\circ} \mathrm{C}\right)$, lyophilized samples were ground to a powder with a Retsch MM 301 mixer mill (Verder Scientific Inc., Newtown, Pennsylvania), weighed to the nearest $0.01 \mathrm{mg}$ on a Cahn Electrobalance (Thermo Fisher Scientific Inc., Waltham, Massachusetts), and placed into pressureresistant vials (Pierce, Rockford, Illinois; $7 \mathrm{~mL}$ ). Samples $(2-4 \mathrm{mg})$ were hydrolyzed in $6 \mathrm{M} \mathrm{HCl}(0.625 \mathrm{~mL}$, oxygen free) under a nitrogen atmosphere $\left(110^{\circ} \mathrm{C}\right.$ for $\left.24 \mathrm{~h}\right)$. After cooling, the $\mathrm{pH}$ of each hydrolysate was adjusted with $6 \mathrm{M} \mathrm{NaOH}$ to fall within the range of 3-5. The derivatizing agent 6aminoquinolyl- $N$-hydroxysuccinimidyl carbamate (AQC) was synthesized as described by Cohen \& Michaud (1983). An aliquot $(50 \mu \mathrm{L})$ of 'neutralized' hydrolysate was mixed with $50 \mu \mathrm{L}$ of $0.5 \mathrm{M}$ borate buffer $(\mathrm{pH} 8.8)$ and derivatized with $26.4 \mu \mathrm{L}$ of a $10 \mathrm{mM}$ AQC solution in acetonitrile. Samples were filtered and the derivatives were separated and quantified with a Waters HPLC (2690 Separation Module; Waters Corp, Milford, Massachusetts), using a Supelco Discovery HS C18 column $(5.0 \mu \mathrm{m}, 250 \mathrm{~mm} \times 4.6 \mathrm{~mm})$ with a $\mathrm{C} 18$ guard column. The gradient used was initially $100 \%$ A (pH5.05 acetate buffer) $/ 0 \%$ B (60\% aqueous acetonitrile), increasing to $2 \% \mathrm{~B}$ at $0.5 \mathrm{~min}, 7 \% \mathrm{~B}$ at $10 \mathrm{~min}, 45 \% \mathrm{~B}$ at $48 \mathrm{~min}$ and returning to $0 \% \mathrm{~B}$ at $53 \mathrm{~min}$. The flow rate was $1.0 \mathrm{~mL} \mathrm{~min}^{-1}$ and the column temperature was $35^{\circ} \mathrm{C}$. Peaks were detected with a Waters 996 photodiode array detector at the wavelength of maximum absorbance $(248 \mathrm{~nm})$. Total amino acids were quantified excluding the ammonia peak because ammonia is produced by the deamination of certain amino acids during hydrolysis, as well as by $L$. dispar larvae, both of which would confound measurements of PAE. Standard curves were prepared from hydrolyzed tobacco leaf protein (fraction 1; primarily RuBisCO; provided by M. M. Martin, University of Michigan) as a representative foliar protein. Amino acid composition and protein quantity remained stable in oak leaf disks during 1-day feeding periods (Barbehenn et al., 2013b).

Water was measured in each of the feeding experiments by weighing leaf disks before and after they were oven dried $\left(70{ }^{\circ} \mathrm{C}\right)$.

Sugars were measured with an enzymatic method (Zhao et al., 2010). Briefly, ground lyophilized leaf samples (10 mg) and frass samples $(20 \mathrm{mg}$ ) were extracted with $80 \%$ ethanol $\left(600 \mu \mathrm{L}, 30 \mathrm{~min}\right.$ at $\left.45^{\circ} \mathrm{C}\right)$ with shaking, followed by centrifugation ( $8000 \mathrm{~g}$ for $5 \mathrm{~min}$ ). The supernatant solutions from three extractions were pooled, and then clarified with activated charcoal $(50 \mathrm{mg}$ for $10 \mathrm{~min}$ ), followed by centrifugation $(8000 \mathrm{~g}$ for $5 \mathrm{~min})$. Aliquots of the solutions $(20 \mu \mathrm{L}$ from leaves, $40 \mu \mathrm{L}$ from frass) were dried in a 96 -well microplate $\left(60^{\circ} \mathrm{C}\right.$ for $45 \mathrm{~min}$ ). Dried samples and standards were resolubilized in $40 \mu \mathrm{L}$ of double-distilled water, to which $100 \mu \mathrm{L}$ of glucose assay reagent (Sigma Chemical Co., St Louis, Missouri; G3293) was added. Total sugars were measured as glucose by adding $20 \mu \mathrm{L}$ aliquots of invertase (for hydrolyzing sucrose) and phosphoglucose isomerase (for converting fructose to glucose) to each sample well (Zhao et al., 2010). Plates were mixed, incubated for $60 \mathrm{~min}\left(37^{\circ} \mathrm{C}\right)$, and the absorbance of each well was recorded at $340 \mathrm{~nm}$. Sample blanks were prepared to correct for the absorbance of interfering compounds. Glucose standards $(0-15 \mu \mathrm{g})$ were run on each microplate to produce standard curves for quantifying total sugars in the samples. Sucrose and fructose standards were run to confirm that they were quantitatively converted to glucose in the assay conditions. No correction for the mass of water gained during sucrose hydrolysis was made, thus overestimating this sugar by $4 \%$. Preliminary measurements of free glucose, fructose and sucrose concentrations in leaves indicated that they were present in a ratio of $1: 1.5: 3$. 
Starch was measured in the extracted pellets remaining from leaf and frass samples (Zhao et al., 2010). After the addition of $1 \mathrm{~mL}$ of double-distilled water to each tube, the pellets were boiled for $1 \mathrm{~h}$. Starch was then converted to glucose by amylase and amyloglucosidase. Glucose liberated from starch was measured with the glucose assay reagent, as described above. Sample blanks were prepared to correct for the absorbance of interfering compounds. The mass of glucose was corrected $(\times 0.90)$ to account for the mass of water gained during starch hydrolysis. High starch levels measured in the frass of some larvae was confirmed by repeated analysis. All reagents were purchased from Sigma Chemical Co.

Total fibre was measured with the neutral detergent fibre (NDF) assay, modified from Van Soest \& Wine (1967) by eliminating the use of decahydronaphthalene, sodium sulphite, and the acetone wash. Ground samples ( $40 \mathrm{mg}$ ) were analyzed from three replicate dates in each experiment. Samples were placed in weighed 2-mL plastic centrifuge tubes with screw-cap lids. Samples were extracted in the neutral detergent solution $(1.5 \mathrm{~mL})$ at $100^{\circ} \mathrm{C}$ for $1 \mathrm{~h}$. After cooling and centrifugation ( $8000 \mathrm{~g}$ for $5 \mathrm{~min}$ ), the supernatant solutions were removed. The extraction was repeated. Fibre pellets were dispersed in distilled water $(1.5 \mathrm{~mL})$, and washed free of detergent in a shaker for $30 \mathrm{~min}$ (ambient temperature). The fibre was pelleted by centrifugation. Supernatant solutions were discarded, and the rinsing procedure was repeated two more times. Fibre samples were dried $\left(70^{\circ} \mathrm{C}\right)$ for $24 \mathrm{~h}$ in the open-topped tubes. The tube and fibre were weighed together, and the weight of the fibre was determined by subtracting the tube weight from the total weight. The percentage of fibre was calculated as (final dry weight)/(initial dry weight $) \times 100$. Control tubes $(n=3)$ taken through the entire procedure were used to correct for the mass lost from the tubes $(<1 \mathrm{mg})$. Neutral detergent fibre includes cellulose, hemicellulose and lignin but not pectin. To distinguish cellulose, hemicellulose and lignin, the NDF assay was followed on the same samples by the acid detergent fibre (ADF) assay and then an assay for lignin.

The ADF solution was prepared by dissolving $1 \mathrm{~g}$ hexadecyltrimethylammonium bromide in $97.2 \mathrm{~mL}$ of distilled water, containing $2.8 \mathrm{~mL}$ of sulphuric acid. The ADF solution $(1.5 \mathrm{~mL})$ was added to NDF pellets in their original tubes, which were boiled for $1 \mathrm{~h}$. The pellets remaining after centrifugation $(8000 \mathrm{~g}$ for $5 \mathrm{~min}$ ) were extracted a second time, after which the pellets were washed three times with $1.5 \mathrm{~mL}$ of distilled water ( $30 \mathrm{~min}$, ambient temperature with shaking). Fibre samples were dried $\left(70^{\circ} \mathrm{C}\right)$ for $24 \mathrm{~h}$ in the open-topped tubes, and the remaining sample weights were determined by subtracting the tube weights.

Lignin (Klason) was determined by treating the ADF pellets with $72 \%$ sulphuric acid (Dence, 1992). Briefly, pellets were shaken for $1 \mathrm{~h}\left(30^{\circ} \mathrm{C}\right)$ in their original tubes. The entire contents of the tubes were transferred to $15-\mathrm{mL}$ centrifuge tubes (plug-seal screw cap; Corning Inc., Lowell, Massachusetts), after which the sulphuric acid was diluted 1:12 with double-distilled water. Diluted samples were boiled for $4 \mathrm{~h}$. After further dilution to a total of $14.5 \mathrm{~mL}$, the samples were centrifuged $(2000 \mathrm{~g}$ for $15 \mathrm{~min})$. Supernatant solutions were largely discarded, and the lignin pellets were resuspended and returned to the original tubes for washing and drying, as described above. Cellulose was determined as the difference between ADF and lignin. Hemicellulose was determined as the difference between NDF and ADF.

\section{Food particle size}

Food particles were dissected from the foreguts of fifthinstar larvae on 9 May, 25 May and 27 June 2012 after a 2-day period of feeding on leaf disks $(n=12-15$ larvae per date). The particles were dispersed in $500 \mu \mathrm{L}$ of $50 \%$ methanol and stored at $-80^{\circ} \mathrm{C}$. Samples were thawed, centrifuged $(8000 \mathrm{~g}$ for $3 \mathrm{~min}$ ), and the supernatant solutions were removed. To increase visual contrast, particles were stained with toluidine blue $\mathrm{O}(30 \mu \mathrm{L}, 0.01 \%$ in water for $1 \mathrm{~min})$. Stained particles were mixed with $500 \mu \mathrm{L}$ of water to rinse excess stain, centrifuged and the supernatant solutions were removed. Stained particles were resuspended in $500 \mu \mathrm{L}$ of water, and a $40-\mu \mathrm{L}$ aliquot was placed on a microscope slide with a cover slip. Photographs were taken with a Leica stereomicroscope ( $\times 10$ magnification). All particles greater than $0.1 \mu \mathrm{m}^{2}$ were measured using IMAGE PRO PLUS (MediaCybernetics Inc., Rockville, Maryland). Data were exported to EXCEL (Microsoft, Redmond, California) for graphical analysis, using bin sizes of $10 \mu \mathrm{m}^{2}$. Occasional particles greater than $0.37 \mathrm{~mm}^{2}$ were not included in the analysis.

\section{Protein assimilation efficiency}

Newly-moulted fifth-instar larvae were fed oak leaves for a 3-day period in experiments that were begun on 7 May, 22 May and 25 June 2012. Larvae ( $n=15$ per experiment) were kept in 35-mL snap-cap plastic cups. Groups of three to seven freshly cut leaf disks were weighed for each larva daily. A moistened paper filter was placed in the bottom of each cup, and hydrated daily, to keep the leaf disks turgid. Uneaten food was dried $\left(70^{\circ} \mathrm{C}\right)$ each day to determine the amount eaten. Representative leaf disks were weighed fresh and after drying to estimate the dry weight of food given to each larva on each day. Additional leaf disks were frozen $\left(-80^{\circ} \mathrm{C}\right)$ daily and lyophilized. Frass was collected daily, and kept separately for each larva in screw-cap centrifuge tubes at $-80^{\circ} \mathrm{C}$. After 3 days of feeding, larvae were starved for a 3 -h period and then fed a piece of artificial diet. All remaining frass pellets composed of leaf material were combined with the frass for each caterpillar, frozen and lyophilized. Protein was measured as total amino acids (peptide bound + free) in $\mathrm{HCl}$ hydrolysates with HPLC, as described above. The nutritional indices examined for protein were:

Protein consumption rate $(\mathrm{PCR})=$ mass of protein ingested/day

Protein assimilation efficiency $(\mathrm{PAE})=$ (mass of protein ingested-mass of protein egested)/mass of protein ingested $\times 100$

Protein assimilation rate $(\mathrm{PAR})=($ mass of protein ingested - mass of protein egested)/day 
PAE is identical to the 'approximate digestibility' of protein. PAE is 'approximate' as a result of the inclusion of nonplant protein in the frass (e.g. protein from peritrophic membranes and sloughed midgut cells). Protein ingested was calculated as percent protein in leaves $\times$ total mass ingested, and total protein egested was calculated as percent protein in frass $\times$ total mass egested.

Carbohydrate assimilation efficiencies and assimilation rates were measured in the same manner as described for protein by analyzing sugar and starch levels in the food and frass of ten larvae used for measuring PAE.

\section{Protein levels in food particles}

Protein remaining inside ingested leaf particles was measured from samples in the posterior midgut. This method permitted the surrounding gut fluid (containing free protein and amino acids) to be quickly rinsed from the food particles. Fifthinstar larvae ( $n=12-15$ per date) were fed for a 2-day period on disks from immature leaves (beginning 9 May) or on disks from mature leaves (beginning on May 25 or June 27). Larvae were chilled individually $\left(6 \mathrm{~min}\right.$ at $\left.-20^{\circ} \mathrm{C}\right)$, and dissected to remove the entire gut. The contents of the posterior midgut were placed in $500 \mu \mathrm{L}$ of $20 \mathrm{mM} \mathrm{HCl}$ (ambient oxygen), dispersed by shaking, and immediately centrifuged $(8000 \mathrm{~g}$ for $3 \mathrm{~min}$ ). Supernatant solutions were removed and the pellets were lyophilized. Subsamples of the pellets were weighed and hydrolyzed in $6 \mathrm{M} \mathrm{HCl}$. Total amino acid levels were measured with HPLC, as described above.

\section{Waste nitrogen products}

Waste nitrogen products were extracted from frass samples collected during each of the three feeding studies. Frass was lyophilized and ground to a fine powder with a MM 301 mixer mill (Retsch, Germany). Uric acid and ammonium salts were extracted from 5 -mg samples in $500 \mu \mathrm{L}$ of $\mathrm{pH} 2.1$ buffer (containing $10 \mathrm{mg}$ polyvinylpolypyrrolidone) at $60^{\circ} \mathrm{C}$ for $30 \mathrm{~min}$ (Shingfield \& Offer, 1999). Samples from 8 to 15 replicate larvae per treatment group were analyzed. Uric acid was measured with a Waters 2690 Separations Module HPLC, coupled with a Waters 996 photodiode array detector. Uric acid was separated with a pair of connected columns: a Polaris C18 $(3.0 \mu \mathrm{m}, 150 \mathrm{~mm} \times 4.6 \mathrm{~mm})($ Metachem) and a Zorbax Bonus-RP C14 $(3.5 \mu \mathrm{m}, 150 \mathrm{~mm} \times 4.6 \mathrm{~mm}$ ) (Agilent Technologies Inc., Santa Clara, California) with a C18 guard column. A pH3.0 buffer was used as the mobile phase $\left(1.0 \mathrm{~mL} \mathrm{~min}^{-1}, 40^{\circ} \mathrm{C}\right)$ (Shingfield \& Offer, 1999). Uric acid was identified based on its peak retention time and ultravioletvisible spectrum (compared with uric acid standards) and quantified with a uric acid standard curve. Ammonium salts (Lovett et al., 1998) were measured in the frass extracts with the HPLC method used to measure amino acids (above). A standard curve was prepared from ammonium phosphate (Sigma Chemical Co.) by serial dilution in the pH 2.1 buffer. Two other waste nitrogen products formed by some larval
Lepidoptera, allantoin and allantoic acid (Bursell, 1967), were measured with the above HPLC method but were below detectable levels in the frass of $L$. dispar.

\section{Statistical analysis}

Analyses of foliar carbohydrate, water and fibre levels, particle sizes, larval consumption rates, amounts of unextracted protein, faecal protein and waste nitrogen levels were compared between dates with one-way analysis of variance (ANOVA) (SAS Institute, 2010). The assimilation efficiencies of total dry mass, protein and carbohydrates were compared between dates with analysis of covariance, using egested masses as main factors and ingested masses as covariates. The normality of the residuals was confirmed with the Shapiro-Wilk test (PROC MIXED). Post-hoc multiple comparisons were made using the probabilities of differences between least squares means (PROC MIXED). These comparisons tested a priori hypotheses. Therefore, $P=0.05$ was used to determine statistical significance. Foliar protein levels could not be transformed to meet the assumptions of ANOVA, and were analyzed with a Kruskal-Wallis test. Individual larvae were used as replicates for all experiments on insects. (For sample sizes, see Materials and methods and Results.) Replicates for oak leaf analyses were days within experiments ( $n=3$ per experiment).

\section{Results}

\section{Foliar nutritional quality}

As red oak leaves matured during a 2-week period in May, their protein levels declined by only $9 \%(P=0.121)$ (Table 1$)$. Protein levels remained at a similar level through June. By contrast, water levels declined significantly by $17 \%$ during leaf maturation, and continued to decline over the next month $(P<0.001$ for each date) (Table 1$)$. Leaf density increased by $74 \%$ in May, and by an additional $26 \%$ in June, consistent with increased toughness (Barbehenn et al., 2013a).

Sugars comprised $73-82 \%$ of total carbohydrates (Table 2). As with protein, carbohydrates remained at similar levels throughout leaf maturation. Thus, ratios of protein :

Table 1. Protein and water levels and leaf density of immature (early May) and mature (late May and June) red oak leaves.

\begin{tabular}{llll}
\hline Date & $\begin{array}{l}\text { Protein } \\
\text { (\% dry weight })\end{array}$ & $\begin{array}{l}\text { Water } \\
(\% \text { fresh weight })\end{array}$ & $\begin{array}{l}\text { Density } \\
\left(\mathrm{mg} \mathrm{cm}^{-2}\right)\end{array}$ \\
\hline 9-11 May & $20.9 \pm 0.5^{\mathrm{a}}$ & $71.9 \pm 0.2^{\mathrm{c}}$ & $3.8 \pm 0.3^{\mathrm{a}}$ \\
25-27 May & $19.1 \pm 0.5^{\mathrm{a}}$ & $60.0 \pm 1.1^{\mathrm{b}}$ & $6.6 \pm 0.4^{\mathrm{b}}$ \\
25-27 June & $18.7 \pm 1.2^{\mathrm{a}}$ & $54.8 \pm 0.1^{\mathrm{a}}$ & $8.3 \pm 0.6^{\mathrm{c}}$ \\
& $P=0.118$ & $P<0.001$ & $P=0.002$ \\
\hline
\end{tabular}

Protein was measured as total amino acids (polypeptide-bound plus free) in acid hydolysates. Density was measured on a dry weight basis. Data are presented as the mean $\pm \mathrm{SE}$ ( $n=3$ days/date for all measurements). Summary statistics followed by different superscript lowercase letters are significantly different $(P<0.05)$. 
Table 2. Carbohydrate and fibre composition of immature (early May) and mature (late May and June) red oak leaves.

\begin{tabular}{|c|c|c|c|c|c|c|c|}
\hline Date & $\begin{array}{l}\text { Sugars } \\
(\% \mathrm{DW})\end{array}$ & $\begin{array}{l}\text { Starch } \\
(\% \mathrm{DW})\end{array}$ & $\begin{array}{l}\text { Total carbohydrate } \\
\text { (\% DW) }\end{array}$ & $\begin{array}{l}\text { Cellulose } \\
\text { (\% DW) }\end{array}$ & $\begin{array}{l}\text { Hemicellulose } \\
\text { (\% DW) }\end{array}$ & $\begin{array}{l}\text { Lignin } \\
\text { (\% DW) }\end{array}$ & $\begin{array}{l}\text { Total fibre } \\
\text { (\% DW) }\end{array}$ \\
\hline 9-11 May & $6.0 \pm 0.4^{\mathrm{a}}$ & $2.2 \pm 0.3^{\mathrm{a}}$ & $8.2 \pm 0.8^{\mathrm{a}}$ & $8.1 \pm 0.7^{\mathrm{a}}$ & $11.4 \pm 0.8^{\mathrm{a}}$ & $5.8 \pm 0.5^{\mathrm{a}}$ & $25.3 \pm 0.4^{\mathrm{a}}$ \\
\hline 25-27 May & $7.0 \pm 0.3^{\mathrm{a}}$ & $2.3 \pm 0.3^{\mathrm{a}}$ & $9.3 \pm 0.3^{\mathrm{a}}$ & $13.3 \pm 0.1^{\mathrm{b}}$ & $12.8 \pm 1.0^{\mathrm{a}}$ & $9.7 \pm 0.2^{\mathrm{b}}$ & $34.7 \pm 0.8^{\mathrm{b}}$ \\
\hline \multirow[t]{2}{*}{ 25-27 June } & $7.0 \pm 0.4^{\mathrm{a}}$ & $1.5 \pm 0.5^{\mathrm{a}}$ & $8.5 \pm 0.9^{\mathrm{a}}$ & $12.3 \pm 0.9^{b}$ & $12.9 \pm 0.8^{\mathrm{a}}$ & $8.9 \pm 0.6^{b}$ & $34.0 \pm 1.3^{\mathrm{b}}$ \\
\hline & $P=0.242$ & $P=0.503$ & $P=0.668$ & $P=0.004$ & $P=0.464$ & $P=0.007$ & $P=0.002$ \\
\hline
\end{tabular}

DW, dry weight. Protein was measured as total amino acids (polypeptide-bound plus free) in acid hydolysates. Data are presented the as mean $\pm \operatorname{SE}(n=3$ replicate days/date for all measurements). Summary statistics followed by different superscript lowercase letters are significantly different $(P<0.05)$. Total fibre does not include pectin.

Table 3. Consumption and assimilation of immature (early May) and mature (late May and June) red oak leaves and protein by fifth-instar Lymantria dispar larvae.

\begin{tabular}{|c|c|c|c|c|c|}
\hline Date & $\begin{array}{l}\text { Total } \\
\text { consumption } \\
\text { rate }\left(\mathrm{mg} \mathrm{day}^{-1}\right)\end{array}$ & $\begin{array}{l}\text { Total } \\
\text { assimilation } \\
\text { efficiency }(\%)\end{array}$ & $\begin{array}{l}\text { Protein } \\
\text { consumption } \\
\text { rate }\left(\mathrm{mg} \mathrm{day}^{-1}\right)\end{array}$ & $\begin{array}{l}\text { Protein } \\
\text { assimilation } \\
\text { efficiency }(\%)\end{array}$ & $\begin{array}{l}\text { Protein } \\
\text { assimilation } \\
\text { rate }\left(\mathrm{mg} \mathrm{day}^{-1}\right)\end{array}$ \\
\hline 9-11 May & $100.5 \pm 1.3^{\mathrm{c}}$ & $36.1 \pm 0.9^{c}$ & $21.0 \pm 0.3^{\mathrm{c}}$ & $70.8 \pm 1.0^{\mathrm{b}}$ & $14.9 \pm 0.3^{\mathrm{c}}$ \\
\hline 25-27 May & $80.9 \pm 2.1^{\mathrm{b}}$ & $29.2 \pm 0.5^{\mathrm{b}}$ & $15.4 \pm 0.5^{\mathrm{b}}$ & $47.7 \pm 0.8^{\mathrm{a}}$ & $7.4 \pm 0.2^{\mathrm{b}}$ \\
\hline \multirow[t]{2}{*}{ 25-27 June } & $68.1 \pm 3.7^{\mathrm{a}}$ & $26.1 \pm 0.8^{\mathrm{a}}$ & $12.7 \pm 0.8^{\mathrm{a}}$ & $48.2 \pm 1.2^{\mathrm{a}}$ & $6.1 \pm 0.4^{\mathrm{a}}$ \\
\hline & $P<0.001$ & $P<0.001$ & $P<0.001$ & $P<0.001$ & $P<0.001$ \\
\hline
\end{tabular}

Assimilation $=$ mass ingested - mass egested. Data are presented as the mean \pm SE $(n=13-15$ for all measurements). Summary statistics followed by different superscript lowercase letters are significantly different $(P<0.05)$.

carbohydrate remained in the range of 2.0-2.4 in mature and young leaves, respectively. As expected, when lush oak leaves matured, total fibre increased significantly by $37 \%(P=0.002)$, but no further change in fibre was observed in June. The fibre components that explained this increase were cellulose and lignin, whereas hemicellulose levels did not increase significantly (Table 2).

\section{Protein assimilation}

The protein in immature leaves was assimilated efficiently by $L$. dispar larvae but, within a period of 2 weeks, PAE dropped by $33 \%(P<0.001)$ (Table 3$)$. This lower PAE persisted into the summer. The combined effects of decreased PAE and decreased protein consumption rate cut the protein assimilation rate in half for larvae feeding on recently mature leaves $(P<0.001)$ because PAR $=$ protein consumption rate $\times$ PAE. Total consumption rate $(\mathrm{CR})$ and assimilation efficiency (AE) of larvae also decreased significantly on recently mature leaves but by approximately $19 \%$, compared with a $27 \%$ and $33 \%$ drop in protein consumption rate and PAE, respectively. Decreased AE was consistent with increased levels of fibre (indigestible) and a decrease in protein assimilation. These results are similar to previous observations (Barbehenn et al., 2013a), but they show the narrow window of time in which major changes occurred.

\section{Carbohydrate assimilation}

Sugars (glucose, fructose and sucrose) were assimilated with extremely high efficiencies (Table 4). By contrast, starch was poorly digested from leaves of all ages. Although there were statistically significant decreases in starch and total carbohydrate assimilation efficiencies from recently mature leaves, high assimilation efficiencies from fully mature summer leaves suggested that this relatively small effect was not related

Table 4. Assimilation of carbohydrates from immature (early May) and mature (late May and June) red oak leaves by fifth-instar Lymantria dispar larvae, as well as ratios of protein : carbohydrate assimilation rates.

\begin{tabular}{|c|c|c|c|c|c|}
\hline Date & $\begin{array}{l}\text { Sugar } \\
\text { assimilation } \\
\text { efficiency }(\%)\end{array}$ & $\begin{array}{l}\text { Starch } \\
\text { assimilation } \\
\text { efficiency }(\%)\end{array}$ & $\begin{array}{l}\text { Carbohydrate } \\
\text { assimilation } \\
\text { efficiency }(\%)\end{array}$ & $\begin{array}{l}\text { Carbohydrate } \\
\text { assimilation } \\
\text { rate (mg/day) }\end{array}$ & $\begin{array}{l}\text { Protein AR: } \\
\text { Carbohydrate } \\
\text { AR ratio }\end{array}$ \\
\hline 9-11 May & $96.1 \pm 0.3^{\mathrm{a}}$ & $53.5 \pm 3.0^{\mathrm{b}}$ & $84.7 \pm 0.9^{b}$ & $7.2 \pm 0.2^{\mathrm{c}}$ & $2.05 \pm 0.04^{\mathrm{b}}$ \\
\hline 25-27 May & $97.4 \pm 0.2^{b}$ & $31.9 \pm 3.4^{\mathrm{a}}$ & $80.9 \pm 0.9^{\mathrm{a}}$ & $6.2 \pm 0.2^{b}$ & $1.20 \pm 0.03^{\mathrm{a}}$ \\
\hline \multirow[t]{2}{*}{$25-27$ June } & $97.9 \pm 0.1^{b}$ & $40.1 \pm 5.0^{\mathrm{b}}$ & $86.3 \pm 1.0^{\mathrm{b}}$ & $5.2 \pm 0.4^{\mathrm{a}}$ & $1.22 \pm 0.04^{\mathrm{a}}$ \\
\hline & $P<0.001$ & $P<0.001$ & $P=0.001$ & $P<0.001$ & $P<0.001$ \\
\hline
\end{tabular}

Assimilation $=$ mass ingested - mass egested. AR, assimilation rate. Data are presented the as mean \pm SE $(n=10-15$ for all measurements). Summary statistics followed by different superscript lowercase letters are significantly different $(P<0.05)$. 


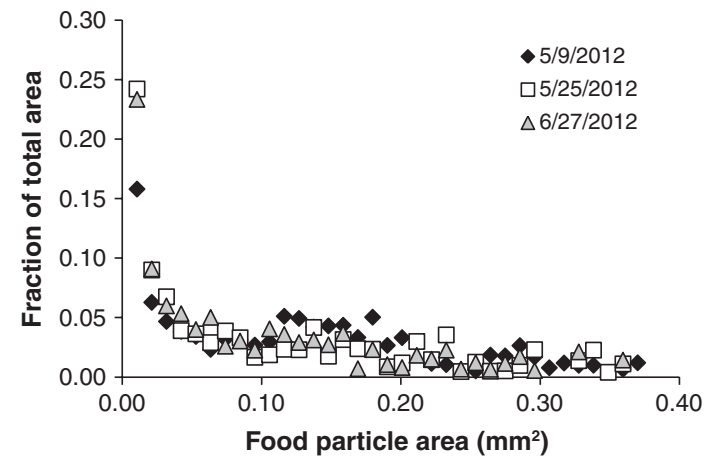

Fig. 1. Particle size distributions in the foreguts of fifth-instar Lymantria dispar larvae feeding on immature (9 May 2012) and mature (25 May and 27 June 2012) red oak leaves.

to leaf maturation. It is noteworthy that efficiencies and rates of carbohydrate assimilation from mature leaves did not decrease in the same manner as did PAR (e.g. only a $13 \%$ decrease in carbohydrate assimilation rate was observed from recently mature leaves). Ratios of protein : carbohydrate assimilation rates decreased by $42 \%$ when oak leaves matured, which can be ascribed largely to decreased PAE.

\section{Food particle size}

Contrary to expectation, median particle sizes produced by larvae on immature and mature leaves did not differ significantly $(P=0.484)$. Instead, larvae chewed all leaves into a wide range of particle sizes (Fig. 1), with the smallest category of particles $\left(0.01-1.1 \mu^{2}\right)$ representing the highest percentage of total particle area. Larvae produced a significantly higher fraction of small particles from mature leaves than from immature leaves $(P<0.01$ for both comparisons) (Fig. 1). Thus, higher PAE on lush leaves was not a result of the larvae chewing them into finer particles, a result that is contrary to one of the earliest mechanisms proposed to explain the reduced nutrient value of mature foliage.

\section{Protein levels in food particles and frass}

Food particles taken from the posterior midgut contained $36 \%$ higher levels of protein when larvae fed on recently mature leaves than on immature leaves (Fig. 2) $(P=0.008)$. When larvae fed on mature leaves in June, there was $49 \%$ more protein retained in the food particles $(P<0.001)$. These results were consistent with the second mechanism examined; the extractability of foliar protein decreased from mature leaves. As with food particles, protein levels in the frass were $37-48 \%$ higher from mature than immature leaves $(P<0.001$ for all mature leaves). Therefore, the protein remaining in the frass represents the fraction that could not be extracted from the ingested leaf tissues, rather than protein that was extracted but not assimilated. It can be calculated that two-thirds of the decrease in PAE (i.e. a decrease to 56\% PAE) is explained by the increase in unextractable protein in mature leaf tissues.

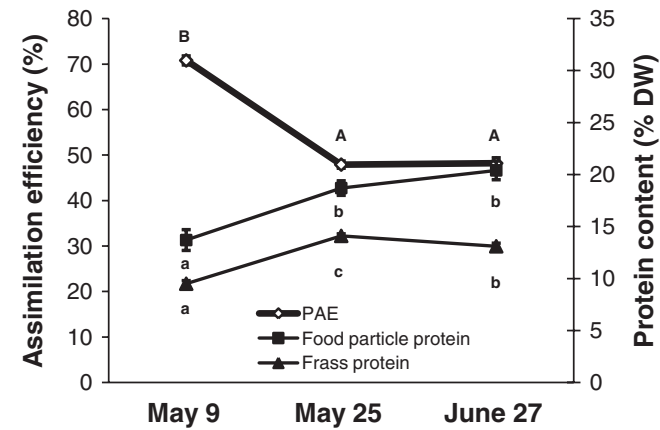

Fig. 2. Protein assimilation efficiency (PAE) of fifth-instar Lymantria dispar on immature and mature red oak leaves, and levels of protein remaining in food particles and frass from larvae on these leaves. Dissections to measure protein inside food particles were performed on the given dates. Separate sets of larvae were used for feeding experiments to measure PAE and frass protein, which were performed for 3-day periods beginning on 7 May, 22 May and 25 June 2012. Protein was measured as total amino acids (peptide-bound plus free) in acid hydolysates. Different letters designate significantly different means within each series $(P<0.01)$. DW, dry weight.

Table 5. Water consumption and waste nitrogen excretion by Lymantria dispar larvae that fed on immature (early May) or mature (late May and June) red oak leaves.

\begin{tabular}{|c|c|c|c|c|}
\hline Date & $\begin{array}{l}\text { Water } \\
\text { consumption } \\
\text { rate } \\
\left(\mathrm{mg} \mathrm{day}^{-1}\right)\end{array}$ & $\begin{array}{l}\text { Uric acid } \\
(\% \text { DW })\end{array}$ & $\begin{array}{l}\text { Ammonium } \\
\text { salts } \\
(\% \mathrm{DW})\end{array}$ & $\begin{array}{l}\text { Total waste } \\
\text { nitrogen } \\
\text { (\% DW) }\end{array}$ \\
\hline 9-11 May & $247 \pm 4^{c}$ & $0.68 \pm 0.04^{\mathrm{b}}$ & $0.82 \pm 0.06^{\mathrm{c}}$ & $1.50 \pm 0.09^{\mathrm{c}}$ \\
\hline 25-27 May & $122 \pm 3^{b}$ & $0.11 \pm 0.01^{\mathrm{a}}$ & $0.27 \pm 0.04^{\mathrm{b}}$ & $0.39 \pm 0.05^{b}$ \\
\hline \multirow[t]{2}{*}{$25-27$ June } & $84 \pm 5^{\mathrm{a}}$ & $0.10 \pm 0.02^{\mathrm{a}}$ & $0.02 \pm 0.02^{\mathrm{a}}$ & $0.12 \pm 0.02^{\mathrm{a}}$ \\
\hline & $P<0.001$ & $P<0.001$ & $P<0.001$ & $P<0.001$ \\
\hline
\end{tabular}

Data are presented as the mean $\pm \mathrm{SE}$ ( $n=8-15$ /date for all measurements). Summary statistics followed by different superscript lowercase letters are significantly different $(P<0.05)$.

\section{Water consumption and waste nitrogen production}

The consumption rate of water decreased by $51 \%$ from early to late May, and by $66 \%$ by late June $(P<0.001$ for both dates) (Table 5). This decrease resulted from both decreased foliar water levels and decreased total CR (Tables 1 and 2). However, the decreased consumption of water in mature leaves was not associated with increased levels of waste nitrogen products (Table 5). Instead, the excretion of uric acid was significantly higher from larvae on immature leaves $(P<0.001)$. The excretion of ammonium salts was also significantly higher from larvae on immature (high-water) leaves, rather than on mature leaves $(P<0.001)$ and was below detection from many larvae in June. Thus, total waste nitrogen levels were positively associated with total protein assimilated $\left(R^{2}=0.894, P<0.001\right)$, which is the opposite of the expected pattern if low water levels limited growth, and excess protein were metabolized and excreted. In addition, only small amounts of free amino acids (i.e. $0.23 \pm 0.03 \%$ dry 
weight) were present in the frass of insects on immature and mature leaves (compared with over $10 \%$ dry weight total amino acids).

\section{Discussion}

As expected from previous work on the L. dispar-red oak system, larvae assimilate protein more efficiently from immature leaves than from mature leaves (Barbehenn et al., 2013a). The present study shows that the entire seasonal decrease in PAE occurs rapidly (in less than 2 weeks) in association with the completion of leaf expansion. This rapid maturation process is characterized by increased levels of fibre and decreased levels of water but no marked changes in protein or carbohydrate levels. The main purpose of the present study was to examine why caterpillar PAE decreases in association with leaf maturation. The fact that both the rinsed food particles and frass from L. dispar contain increased protein levels when mature leaves are eaten points to the same major finding, that protein in food particles becomes significantly less extractable during leaf maturation.

The present results place a greater emphasis on protein extractability and less emphasis on seasonal changes in concentrations of nutrients to explain protein availability. The major portion of the drop in nitrogen levels in tree leaves commonly occurs from the time of bud break through the production of primordial leaves (which are rich in nucleic acid nitrogen). After leaf expansion nears completion, there is commonly little change in protein levels (Feeny, 1970; Schroeder \& Malmer, 1980; Wint, 1981; Williams et al., 1998; Barbehenn et al., 2013a; present study; but see Coley et al., 2006). It is noteworthy that the range of protein found in red oak leaves during this study coincides with the optimum range selected by $L$. dispar larvae from artificial diets (Stockoff, 1993).

High assimilation efficiencies for sugars (e.g. $>90 \%$ ) are reported in previous studies of caterpillars on foliage (Horie et al., 1985; Terra et al., 1987). However, starch granules in planta are digested with widely variable and sometimes negligible efficiencies by different species of caterpillars (Waldbauer, 1968; Harvey, 1975). Low efficiencies of starch assimilation could be related to the inability of starch to diffuse through cell walls, in contrast to small molecules such as sugars (Baron-Epel et al., 1988). However, starch assimilation efficiencies have only small effects on total carbohydrate assimilation rates because sugars are assimilated efficiently and comprise the major form of carbohydrate in red oak leaves. Importantly, little evidence is found to support the hypothesis that PAE decreases as a result of decreased carbohydrate assimilation efficiency from mature leaves. In addition, neither consumption rates, nor growth rates of $L$. dispar larvae increase significantly when sucrose or fructose is coated on mature red oak leaves at $1.5 \%$ of leaf dry weight (R. $\mathrm{V}$. Barbehenn, unpublished data), which is inconsistent with carbohydrate limitation.

Some studies on protein utilization conclude that the low levels of water present in mature tree leaves limit caterpillar growth, and consequently reduce their utilization of protein (Scriber, 1977, 1979; Martin \& Van't Hof, 1988). Therefore, two potential post-ingestive responses of waterlimited caterpillars would be the increased production of waste nitrogen compounds (from metabolized excess amino acids) and/or the intentional decrease of PAE (reducing the costs of waste nitrogen production). The present results do not support these physiological scenarios. First, larvae that fed on mature leaves do not produce higher levels of waste nitrogen compounds. Instead, waste nitrogen levels are much higher on lush, young leaves. This is interpreted as a result of the mismatch between the balance of amino acids in foliar protein and the balance required for larval protein synthesis (Barbehenn et al., 2013b) (i.e. unneeded amino acids will end up excreted as waste nitrogen in proportion to the amount of foliar protein used for growth). Most importantly, protein is physically trapped in larger amounts in mature than in young leaf particles ingested by larvae. Thus, protein is not extracted to a similar extent from all leaf ages, and absorbed from the midgut to a lesser extent by larvae on mature leaves. Other signs of water limitation observed previously included decreased efficiencies of converting assimilated matter to body mass (ECD) (Scriber, 1977; Martin \& Van't Hof, 1988). It is noteworthy, therefore, that no significant changes in ECD are observed in $L$. dispar larvae on mature versus immature oak leaves (Barbehenn et al., 2013a). The different results obtained in the present study compared to previous work are likely a result of the structural effects of leaf tissues on protein availability versus artificial diets (Martin \& Van't Hof, 1988), and the smaller range of water levels in maturing oak leaves (72\% to 60\%) compared with other work conducted with wilted leaves (e.g. 90\% to 50\%) (Scriber, 1977). Based on this evidence, lower water consumption rates by $L$. dispar larvae on mature leaves do not appear to explain decreased PAE from mature oak leaves.

The structural and morphological changes that occur during the rapid maturation of leaves are well studied (Maksymowych, 1973; Dale, 1982) but not with respect to their potential effects on protein assimilation by insect herbivores. Increased fibre in mature leaves is associated with increased leaf toughness and decreased consumption rate (Choong, 1996; Barbehenn et al., 2013a) but leaf tissue processing is no less efficient by L. dispar larvae on mature than on immature leaves. Nonetheless, fibre might still affect PAE. The cell walls in immature leaves are thin (approximately $0.1 \mu \mathrm{m}$ ) (Doblin et al., 2003). By contrast, mature cell walls are greatly thickened with fibre (up to several $\mu \mathrm{m}$ thick) and contain increased proportions of lignin, pectin and cell wall proteins. Some of these changes are evident in the oak leaves used in the present study, and any of these changes could potentially decrease protein extractability. For example, increased amounts of lignin in cell walls greatly increase leaf toughness, and also decrease the porosity of the cell wall (adding 'water-proofing') (Boudet, 2003). Pectin is considered to have strong effects on the permeability properties of cell walls (Baron-Epel et al., 1988; but see Fujino \& Itoh, 1998). Cell wall-bound protein also decreases the permeability of cell walls and increases their strength (Brisson et al., 1994). Bound protein increases in red oak during leaf maturation 
from $4 \%$ to $11 \%$ of total protein (Barbehenn et al., 2013b). It can be calculated, however, that the increase in cell wallbound protein makes only a trivial $(<4 \%)$ contribution to the overall drop in PAE. Unexpectedly, condensed tannins in red oak cell walls do not increase significantly during leaf maturation (Barbehenn et al., 2013a). Cell membranes are also unlikely to limit protein extraction because membranes are degraded rapidly in the guts of caterpillars (Barbehenn, 1992). Presumably, protein extraction is a passive process that follows the disruption of cell membranes and the exposure of leaf tissues to the highly basic $\mathrm{pH}$ of caterpillar midgut fluid (Schultz \& Lechowicz, 1986). The importance of cell wall structure is also suggested in the seminal study of Feeny (1970), in which it is shown that grinding the leaves of young and mature Quercus robur eliminates their nutritional differences for a caterpillar.

Although the mandibles of L. dispar caterpillars lack a true molar region or an array of non-incisor teeth (Bernays \& Janzen, 1988), they are able to chew leaves efficiently. The present study provides the first evidence, of which we are aware, regarding such a capability. Chewing is apparently accomplished when one mandible crushes an excised leaf piece into a recessed groove in the opposing mandible (Peterson, 1951: fig. L24 E). Lymantria dispar produces food particles with an array of sizes on par with those produced by grasshoppers, which have true molars (Barbehenn, 2005). Surprisingly, caterpillars with chewing mandibles represent less than $20 \%$ of 202 species of Lepidoptera surveyed (Barbehenn, 1992), making snipping mandibles (which produce large food particles) the predominant morphology. Therefore, small particle size may not be the key to extracting foliar protein. Further work is needed to understand whether $L$. dispar extracts a nutritionally significant fraction of foliar protein through the cell walls of intact leaf cells, as do leaf-snipping caterpillars. This evidence would be relevant to the hypothesis that cell wall maturation decreases PAE by decreasing protein extractability.

The results of the present study contribute to an understanding of the nutritional factors that decrease the fitness of $L$. dispar (and possibly other spring-feeding species) when they feed on recently mature tree leaves (Hough \& Pimentel, 1978; Schweitzer, 1979; Schroeder, 1986; Raupp et al., 1988; Parry et al., 1998). Specifically, late-hatching larvae may face a greatly reduced ability to acquire protein if they must feed on mature leaves for a greater part of their developmental period. Any factor that limits protein assimilation might be expected to have a strong impact on caterpillar fitness. The fact that PAE declines in a similar fashion from the mature leaves of both red oak and sugar maple (Barbehenn et al., 2013a) suggests that this phenomenon spans a wide taxonomic range of plants. Thus, high PAE from immature leaves, if it is a general phenomenon, would have potentially important ecological and evolutionary consequences. For example, the nutritional benefits of immature leaves to herbivores, and the high cost to plants from damage to these leaves, may have contributed to the large investment in plant defences commonly found at this stage of development (Herms \& Mattson, 1992; Haruta et al., 2001; Coley et al., 2006).
In conclusion, although protein remains near optimum levels for $L$. dispar in mature oak leaves, the amounts that could be assimilated from these leaves fell to approximately one half of this level. The results of the present study therefore suggest a general mechanism to help explain the widely documented decrease in the nutritional quality of the mature leaves of many tree species for herbivorous insects: lower protein extractability decreases PAE. Although carbohydrates and water are also essential nutrients, variation in their levels does not explain decreased PAE or consumption rate in larvae on mature oak leaves. It is hypothesized that the major changes in cell wall structure during leaf maturation are primarily responsible for decreasing PAE. Support for this hypothesis would provide a 'next step' to help explain the reduced nutritional quality of the mature leaves of some tree species for caterpillars.

\section{Acknowledgements}

We thank Professor Michael M. Martin (Department of Ecology and Evolutionary Biology, University of Michigan) for his critique of the manuscript and for the purified leaf protein; Christine Lokerson (USDA) for providing L. dispar eggs; and Jennifer Knister and Will Nham for research assistance.

\section{References}

Addy, N.D. (1969) Rearing the forest tent caterpillar on and artificial diet. Journal of Economic Entomology, 62, 270-271.

Barbehenn, R.V. (1992) Digestion of uncrushed leaf tissues by leafsnipping larval Lepidoptera. Oecologia, 89, 229-235.

Barbehenn, R.V. (2005) Grasshoppers efficiently process the bundle sheath cells in a $\mathrm{C}_{4}$ grass: implications for patterns of host plant utilization. Entomologia Experimentalis et Applicata, 116, 209-217.

Barbehenn, R.V., Weir, Q. \& Salminen, J.-P. (2008) Oxidation of ingested phenolics in the tree-feeding caterpillar Orgyia leucostigma depends on foliar chemical composition. Journal of Chemical Ecology, 34, 748-756.

Barbehenn, R.V., Jaros, A., Lee, G. et al. (2009a.) Hydrolyzable tannins as 'quantitative defenses': limited impact against Lymantria dispar caterpillars on hybrid poplar. Journal of Insect Physiology, 55, 297-304.

Barbehenn, R.V., Jaros, A., Lee, G. et al. (2009b) Tree resistance to Lymantria dispar caterpillars: importance and limitations of foliar tannin composition. Oecologia, 159, 777-788.

Barbehenn, R.V., Niewiadomski, J., Pecci, C. \& Salminen, J.-P. (2013a) Physiological benefits of feeding in the spring by Lymantria dispar caterpillars on red oak and sugar maple leaves: nutrition versus oxidative stress. Chemoecology, 23, 59-70.

Barbehenn, R.V., Niewiadomski, J. \& Kochmanski, J. (2013b) Importance of protein quality versus quantity in alternative host plants for a leaf-feeding insect herbivore. Oecologia, 173, 1-12.

Baron-Epel, O., Gharyal, P.K. \& Schindler, M. (1988) Pectins as mediators of wall porosity in soybean cells. Planta, 175, 389-395.

Behmer, S.T. (2009) Insect herbivore nutrient regulation. Annual Review of Entomology, 54, 165-187.

Bernays, E.A. (1978) Tannins: an alternative viewpoint. Entomologia Experimentalis et Applicata, 24, 244-253.

Bernays, E.A. \& Janzen, D.H. (1988) Saturniid and sphingid caterpillars: two ways to eat leaves. Ecology, 69, 1153-1160. 
Boudet, A.-M. (2003) Towards an understanding of the supramolecular organization of the lignified cell wall. The Plant Cell Wall ( ed. by J.K.C. Rose), pp. 155-182. Blackwell, U.K.

Brisson, L.F., Tenhaken, R. \& Lamb, C. (1994) Function of oxidative cross-linking of cell wall structural proteins in plant disease resistance. Plant Cell, 6, 1703-1712.

Bursell, E. (1967) The excretion of nitrogen in insects. Advances in Insect Physiology, 4, 33-67.

Choong, M.R. (1996) What makes a leaf tough and how this affects the pattern of Castanopsis fissa leaf consumption by caterpillars. Functional Ecology, 10, 668-674.

Cipollini, D.F. \& Bergelson, J. (2000) Environmental and developmental regulation of trypsin inhibitor activity in Brassica napus. Journal of Chemical Ecology, 26, 1411-1422.

Clissold, F.J., Sanson, G.D., Read, J. \& Simpson, S.J. (2009) Gross vs. net income: how plant toughness affects performance of an insect herbivore. Ecology, 90, 3393-3405.

Clissold, F.J., Tedder, B.J., Conigrave, A.D. \& Simpson, S.J. (2010) The gastrointestinal tract as a nutrient-balancing organ. Proceedings of the Royal Society of London Series B, Biological Sciences, 277, $1751-1759$.

Cohen, S.A. \& Michaud, D.P. (1983) Synthesis of a fluorescent derivatizing reagent, 6-aminoquinolyl-N-hyroxysuccinimidyl carbamate, and its application for the analysis of hydrolysate amino acids via high-performance liquid chromatography. Analytical Biochemistry, 211, 279-287.

Coley, P.D., Bateman, M.L. \& Kursar, T.A. (2006) The effects of plant quality on caterpillar growth and defense against natural enemies. Oikos, 115, 219-228.

Dale, J.E. (1982) The Growth of Leaves. Edward Arnold, U.K.

Dence, C.W. (1992) The determination of lignin. Methods in Lignin Chemistry ( ed. by S.Y. Lin and C.W. Dence), pp. 33-61. SpringerVerlag, New York, New York.

Doblin, M.S., Vergara, C.E., Read, S. et al. (2003) Plant cell wall biosynthesis: making the bricks. The Plant Cell Wall ( ed. by J.K.C. Rose), pp. 183-222. Blackwell, U.K.

Feeny, P.P. (1970) Seasonal changes in oak leaf tannins and nutrients as a cause of spring feeding by winter moth caterpillars. Ecology, 51, 565-581.

Fujino, T. \& Itoh, T. (1998) Changes in pectin structure during epidermal cell elongation in pea (Pisum sativum) and its implications for cell wall architecture. Plant Cell Physiology, 39, 1315-1323.

Haruta, M., Major, I.T., Christopher, M.E. et al. (2001) A Kunitz trypsin inhibitor gene family from trembling aspen (Populus tremuloides Michx.): cloning, functional expression, and induction by wounding and herbivory. Plant Molecular Biology, 46, 347-359.

Harvey, G.T. (1975) Nutritional studies of eastern spruce budworm (Lepidoptera: Tortricidae). II. Starches. Canadian Entomologist, 107, 717-728.

Herms, D.A. \& Mattson, W.J. (1992) The dilemma of plants: to grow or defend. Quarterly Review of Biology, 67, 283-335.

Horie, Y. \& Watanabe, K. (1983) Effect of various kinds of dietary protein and supplementation with limiting amino acids on growth, haemolymph components and uric acid excretion in the silkworm, Bombyx mori. Journal of Insect Physiology, 29, 187-199.

Horie, Y., Nakasone, S., Watanabe, K. et al. (1985) Daily ingestion and utilization of various kinds of nutrients by the silkworm, Bombyx mori (Lepidoptera, Bombycidae). Applied Entomology and Zoology, 20, 159-172.

Hough, J.A. \& Pimentel, D. (1978) Influence of host foliage on development, survival and fecundity of the gypsy moth. Environmental Entomology, 7, 97-102.
Hunter, A.F. \& Lechowicz, M.J. (1992) Foliage quality changes during canopy development of some northern hardwood trees. Oecologia, 89, 316-323.

Karowe, D.N. (1989) Differential effect of tannic acid on two treefeeding Lepidoptera: implications for theories of plant-herbivore chemistry. Oecologia, 80, 507-512.

Liebhold, A.M., Gottschalk, K.W., Muzika, R-M. et al. (1995) Suitability of North American Tree Species to the gypsy moth: A Summary of Field and Laboratory Tests. General Technical Report No NE-211. United States Department of Agriculture Forest Service, Northeastern Forest Experimental Station, Radnor, Pennsylvania.

Lovett, G.M., Hart, J.E., Christenson, L.M. \& Jones, C.G. (1998) Caterpillar guts and ammonia volatilization: retention of nitrogen by gypsy moth larvae consuming oak foliage. Oecologia, 117, 513-516.

Maksymowych, R. (1973) Analysis of Leaf Development. Cambridge University Press, U.K.

Martin, M.M. \& Van't Hof, H.M. (1988) The cause of reduced growth of Manduca sexta larvae on a low-water diet: increased metabolic processing costs or nutrient limitation? Journal of Insect Physiology, 34, 515-525.

Martin, J.S., Martin, M.M. \& Bernays, E.A. (1987) Failure of tannic acid to inhibit digestion or reduce digestibility of plant protein in gut fluids of insect herbivores: implications for theories of plant defense. Journal of Chemical Ecology, 13, 605-621.

Mattson, W.J. (1980) Herbivory in relation to plant nitrogen content. Annual Review of Ecology and Systematics, 11, 119-161.

Montgomery, M.E. (1990) Variation in the suitability of tree species for gypsy moth. Proceedings, USDA Interagency gypsy moth Research Review, General Technical Report No NE-146 ( ed. by K.W. Gottschalk, M.J. Werey and S.I. Smith), pp. 1-13. United States Department of Agriculture Forest Service, Radnor, Pennsylvania.

Parry, D., Spence, J.R. \& Volney, W.J.A. (1998) Budbreak phenology and natural enemies mediate survival of first-instar forest tent caterpillar (Lepidoptera: Lasiocampidae). Environmental Entomology, 27, 1368-1374.

Peterson, A. (1951) Larvae of Insects. Part 1: Lepidoptera and Plant Infesting Hymenoptera. Edwards Brothers, Ann Arbor, Michigan.

Raupp, M.J. \& Denno, R.F. (1983) Leaf age as a predictor of herbivore distribution and abundance. Variable Plants and Herbivores in Natural and Managed Systems ( ed. by R.F. Denno and M.S. McClure), pp. 91-124. Academic Press, New York, New York.

Raupp, M.J., Werren, J.H. \& Sadof, C.S. (1988) Effects of short-term phenological changes in leaf suitability on the survivorship, growth and development of gypsy moth (Lepidoptera: Lymantriidae) larvae. Environmental Entomology, 17, 316-319.

SAS Institute (2010) The SAS System for Windows, Version 9.3 . SAS Institute, Cary, North Carolina.

Schmidt, D. \& Reese, J. (1986) Sources of error in nutritional index studies of insects on artificial diet. Journal of Insect Physiology, 32, 193-198.

Schroeder, L.A. (1986) Changes in tree leaf quality and growth performance of lepidopteran larvae. Ecology, 67, 1628-1636.

Schroeder, L.A. \& Malmer, M. (1980) Dry matter, energy and nitrogen conversion by Lepidoptera and Hymenoptera larvae fed leaves of black cherry. Oecologia, 45, 63-71.

Schultz, J.C. \& Lechowicz, M.C. (1986) Hostplant, larval age, and feeding behavior influence midgut $\mathrm{pH}$ in the gypsy moth (Lymantria dispar). Oecologia, 71, 133-137.

Schweitzer, D.F. (1979) Effects of foliage age on body weight and survival in larvae of tribe Lithophanini (Lepidoptera: Noctuidae). Oikos, 32, 403-408. 
Scriber, J.M. (1977) Limiting effects of low leaf-water content on the nitrogen utilization, energy budget, and larval growth of Hyalophora cecropia (Lepidoptera: Saturniidae). Oecologia, 28, 269-287.

Scriber, J.M. (1979) Effects of leaf-water supplementation upon post-ingestive nutritional indices of forb-, shrub-, vine-, and treefeeding Lepidoptera. Entomologia Experimentalis et Applicata, 25, 240-252.

Scriber, J.M. \& Slansky, F. (1981) The nutritional ecology of immature insects. Annual Review of Entomology, 26, 183-211.

Shingfield, K.J. \& Offer, N.W. (1999) Simultaneous determination of purine metabolites, creatine and pseudouridine in ruminant urine by reversed-phase high performance liquid chromatography. Journal of Chromatography B, 723, 81-94.

Stockoff, B.A. (1993) Protein intake by gypsy moth larvae on homogeneous and heterogeneous diets. Physiological Entomology, 18, 409-419.

Terra, W.R., Valentin, A. \& Santos, C.D. (1987) Utilization of sugars, hemicellulose, starch protein, fat and minerals by Errinyis ello larvae and the digestive role of their midgut hydrolases. Insect Biochemistry, 17, 1143-1147.
Van Soest, P.J. \& Wine, R.H. (1967) Use of detergents in the analysis of fibrous feeds. IV. Determination of plant cell-wall constituents. Journal of the Association of Official Analytical Chemists, 50, $50-55$.

Waldbauer, G.P. (1968) The consumption and utilization of food by insects. Advances in Insect Physiology, 5, 229-289.

Williams, R.S., Lincoln, D.E. \& Norby, R.J. (1998) Leaf age effects of elevated $\mathrm{CO}_{2}$-grown white oak leaves on spring-feeding lepidopterans. Global Change Biology, 4, 235-246.

Wint, G.R.W. (1981) The effect of foliar nutrients upon the growth and feeding of a lepidopteran larva. 22nd Symposium British Ecological Society. $N$ as an Ecological Factor ( ed. by J.A. Lee, S. McNeill and I.H. Rorison), pp. 301-320. Blackwell Scientific Publications, U.K.

Zhao, D., MacKown, C.T., Starks, P.J. \& Kindiger, B.K. (2010) Rapid analysis of nonstructural carbohydrates in grass forage using microplate enzymatic assays. Crop Science, 50, 1537-1545.

Accepted 30 November 2013

First published online 23 January 2014 